\title{
MASS MEDIA ATTRIBUTION TO LOCAL GOVERNMENT INFRASTRUCTURE PERFORMANCE
}

\section{Zainal Aqli}

PhD, Universitas Tujuh Belas Agustus

Address: Jl. Semolowaru Praja No. 45, Surabaya, Indonesia.

E-mail: zainalaqli14269@gmail.com

\begin{abstract}
Mass media is a public communication channel for the government, as well as a detector of field situations, program observer, and reporter to the public on government performance. Responsibility attribution theory sees the presence of two types of attributions: causal attribution and maintenance attribution. This study examines the attribution of mass media to the Public Works Department, Tapin Regency, Republic of Indonesia. News coverage was collected from regional and national news sites between 2015 and 2017. A total of 30 news items are relevant for further analysis. Of these, 24 are known to attribute causal responsibilities to non-governmental actors, while 29 provide attribution of responsibility for maintenance to the government. However, only three stories show the government as an active actor solving the problem completely. These results indicate that the mass media are not interested in the results achieved by the government, but only look at the responses given to problems. The media did not report on the progress or performance of the government's response measures. Theoretically, this study has implications on the theory of attribution of responsibility by asserting that attribution also needs to be seen from temporal dimensions. It is important for government to make partnerships with mass media more actively. The originality of this research lies in the use of the theory of attribution of responsibilities in more detail to inform on the improvement of public administration.
\end{abstract}

Keywords: mass media; government response; attribution of responsibilities; temporal dimension; public relations; causal attribution; maintenance attribution; public works department; knowledge activation; Tapin district.

Citation: Aqli, Z. (2018). Mass Media Attribution to Local Government Infrastructure Performance. Public Administration Issues, Special Issue (electronic edition), pp. 145-162 (in English); DOI: 10.17323/1999-5431-2018-0-5-145-162.

\section{Introduction: Public Administration and Mass Media}

Mass media is an important partner of the government in terms of carrying out development, especially in the field of public management. The role of the media is important: to socialize the plans, implementation, and results of develop- 
ment. The interest of the media in a development sector can strengthen the role of non-governmental actors in development (Wettenberg \& Brinkerhoff, 2016) and, therefore, leads to development in a participatory framework, which is more likely to sustain development.

However, recent media developments have resulted in a situation that does not match expectations. The media often generates anti-public sector sentiment by reporting more negatively than positively to the development process. The Porumbescu study (2016) shows that the more often a citizen reads the online mass media, the more they are dissatisfied with public services and the less trustworthy they perceive the government to be.

Actually the problem lies not in the characteristics of the media, but in the frames created by the media on news and knowledge possessed by the public from non-media sources such as personal experience as well as popular knowledge in the community (Constantinescu, Tedesco, 2007). Of course, the more positive the media attitude toward government, the better the perception in society, because after all, frames created by the media influence public opinion about the quality of government services (Gamson, 1992). The results of news media research repeatedly show results parallel to the public attitudinal survey on various infrastructure issues (Bengston et al., 2005).

In line with this, from the public management side, it is important to look at the news situation created by the media in order to take anticipatory measures to prevent public perception from declining government services. If public perception is good for government services, the government can gain motivation and appreciation from the public, albeit on small matters, thus cumulatively becoming a motivator and a driver of employee job satisfaction, which in turn will improve the performance of public services for the better.

Three previous studies have been conducted to assess the relationship between public management and the mass media. The study by V. Price et al. (1997) was conducted on 135 students who were given news of possible governmentfunded state budget cuts. The results show that the frames created by the news affect students' opinions about government performance. However, the researchers also found that some students have their own opinions that are original and not based on the opinions given by the mass media.

Research in Indonesia was conducted by H. Ridhahani et al. (2016) by studying the influence of media mass media access to bureaucratic mental revolution commitment in the public service in South Kalimantan with one of the research sites in Tapin Regency. The independent variable is access to mass media coverage of the mental revolution, shown by seven indicators including: frequency of media types accessed in general; frequency of the type of information accessed in general; frequency of accessing information about mental revolution; interest in accessing information about mental revolution; the pleasure of accessing information about mental revolution; duration of access to information about mental revolution and intensity in accessing information about mental revolution. Meanwhile, the dependent variable is the commitment of the public service. The results showed a significant relationship between access to news with the commitment of public services. However, since this study uses only one independent variable, 
i.e. the news of the mental revolution, questions arise about the validity of this study and whether or not any other variables affect it.

S. Iyengar's (1989) study addressed this issue by examining the effect of the attribution of responsibilities brought by the media to public opinion on issues of poverty, crime, racial inequality, and terrorism. In this study, Iyengar also used control variables such as political party, liberal-subjective orientation, information, and socio-economic status. The attribution of responsibilities from the media is known to have a significant effect on public opinion, indicating that the media is capable of influencing public opinion.

The relationship between government and society can be analyzed with New Public Management (NPM) theory, developed in the 1980s and 1990s. The theory generates a boost for governments to exit contracts or privatize public services. According to NPM theory, contract companies chosen by market mechanisms can be more efficient and can increase public satisfaction (Wang et al., 2014). Governments need to reduce or rationalize ministries or agencies and submit part of the public services on a contractual basis (Thomas, 2014). Because of this liberating nature, NPM is seen to be based on neo-liberalism.

However, NPM does not merely entrust itself fully to market mechanisms. Basically, the design of public management involves a balance between stakeholders, especially governments, the private sector, and society, just like the old theory of traditional public administration. The difference lies in the larger portion of private and community involvement. Traditional public administration theory results in too much of a government. The government only involves the private sector and the community if it is not able to fulfill the job and the government remains dominant to ensure proper rules and procedures are followed (Wang et al., 2014, p. 160). But even the government cannot guarantee whether the right rules and procedures, which they believe in, will be able to produce optimum results. Therefore, they need to be involved more in public management. Here is the difference between NPM theory and traditional public administration. The purpose of balance design among stakeholders is no longer to play by the right rules and procedures but to help determine and meet agreed performance targets (Wang et al., 2014). That is, the main objective is not on compliance with predetermined rules and processes, but on the ultimate goals expected by both government and the private sector and society. This requires a common interest and cooperation in achieving collective goals based on trust and incentives (Wang et al., 2014).

In addition to efficiency, an important concept that is carried out by NPM is transparency. Transparency is seen as an antonym of corruption. This is because transparency allows the private sector and the public to observe and analyze how the government manages public issues (Ballesteros, 2012). Moreover, transparency also facilitates and accelerates coordination among fellow government agencies. Transparency also drives efficiency because by knowing what is and has been done, others do not need to measure the same thing. Lack of transparency facilitates corruption because supervision is at a minimum.

The efficiency and transparency at the core of NPM is the foundation for the opening and involvement of the private sector and the public in public man- 
agement. One of the private parties that need to be involved is the mass media. The mass media enables efficiency in the delivery of government plans, programs, and performance information. The mass media also allows transparency by asking questions that are considered unclear and have not been presented well in government reports. Because of the nature of NPM as the underlying theory of stakeholder involvement in public management, NPM theory is used in this study as a grand theory. This research focuses on mass media as a stakeholder in NPM and this makes the theory about media to be a middle range theory in this research.

The critical theory of mass media is part of a critical theory that studies the relationship between the role of an institution or organization within the culture of a society. In general, critical theories argue that an institution or organization plays a role beyond its formal role expressed in the documents of the organization. This hidden role is basically an attempt to construct or represent a particular reality based on assumptions and interests. In the context of mass media, this means that the role of the mass media is not merely the sender or reflector of information, but also has the role of constructing or representing the reality of the information it conveys (Hamot et al., 1997).

Correspondingly, the critical theory of the mass media focuses on the interests, assumptions, and basic approaches used by the media in constructing or representing that reality. The mass media is observed as an institution with hidden assumptions, containing irrelevant information conveyed along with relevant information, having biases in the news, confusing facts and opinions in the news, and striving to influence society through its message conveyed with these characteristics (Ibid., 1997).

While all mass media will not be separated from hidden assumptions, biases, and interests, critical theory leads to whatever assumptions, biases, and interests that the media needs to advocate in order to have a positive effect on the relationship between society and government. According to Ridhadhani et al. (2016), this ideal function includes: (1) as the light of society, that is, the role to educate and change the mindset of the community to be more advanced, (2) as information media, that is, disseminator of information for society for the delivery of knowledge to existing conditions and problems, and (3) as entertainment media, namely the role to provide entertainment to the public.

The critical theory of mass media becomes the theory that specifies stakeholders in NPM theory, ie mass media. This specification in turn emphasizes the role of mass media in society, particularly in conveying information about government performance to the public. In the process of delivering this information, there are biases that deviate from the ideal role of the mass media as stakeholders should encourage government efficiency and transparency.

The knowledge-activation model (Price, Tewksbury, 1997) argues that in making decisions, human beings use three considerations, namely the current situation, older remembered knowledge, and basic knowledge. The current situation comes from the context, and can be news from the mass media, but can also come from the direct experience and experience of others who are shared socially. 
From the current situation, the individual selects the feasibility of the attributes of the situation to be used as a consideration. This feasibility is called applicability. In addition to applicability, individuals also have accessibility, which is nothing but the store of knowledge they have in their mind. Accessibility can be temporary, which fades over time as there is no need for use in evaluation, or constant (chronic), which continues to exist in the mind of a person as a basis.

Chronic accessibility, temporary accessibility, and applicability are then used for activation of the human mind when it feels necessary or aroused to give an opinion on something. Activation of thinking selects which of the applicability and accessibility elements are relevant and then used to come up with the conclusion of an opinion on a problem.

An example process is about road damage in an area. In this situation, road damage becomes applicability. This road damage can come from the experience of seeing alone, hearing from others, or obtaining it from the media. This new knowledge is then paired with old knowledge (accessibility). When the person is asked for their opinion on the performance of a government institution for such road damage, the individual activates accessibility and applicability, selects what is relevant, then expresses his opinion. This opinion can be in line with the media, especially if the person has absolutely no prior accessibility. Or, this opinion may differ from the opinion of the media if the old knowledge has different facts and is more dominant than the point that the media is trying to make. As a result, while the media say that the institution is performing poorly, people who have previous experience of the institution performing well - and this experience is more dominant - are more likely to state that the institution is performing well.

The knowledge activation model asserts that one does not merely make public performance opinions based on media coverage. However, the media will have a big impact because the media has a wider range of knowledge. News about road damage in one particular place delivered by the media can be richer in information than the experience of seeing directly or hearing from others. Moreover, the media can be the sole source of knowledge for a person when the problem is reported beyond the reach of personal or others' experiences, such as the coverage of the situation in another country.

In a situation without accessibility, a citizen is forced to rely on the knowledge of the mass media and this is the important role of the mass media in shaping one's opinion. S. Iyengar puts forward the theory of attribution of responsibility for situations like this. According to Iyengar (1991), in a situation of no accessibility, one's opinion is influenced by the statement given by the media about who is responsible for something. Attribution theory of responsibility assumes that everyone tends to exaggerate the role of a party in a situation. This tendency generates polarization of who is responsible for the problem, referred to as causal responsibility, and who is responsible for problem solving, referred to as the maintenance responsibility. Iyengar's research (1989) shows that parties who are perceived to be the cause of the problem will be perceived negatively by the community, while the parties who are viewed as a solution to the problem are perceived positively by society. 
This theory implies that media coverage of a problem will trigger a person to find out who is responsible for the problem and who is responsible for problem solving. If the mass media mentions a government institution as the source of a problem, for example the cause of road damage being ignored and not addressed, then society will perceive that institution to be performing negatively. Meanwhile, if the institution is declared as the source of the solution of the problem, such as reporting on the repair of damaged roads, then society will perceive the institution positively. Cumulative positive effects can be achieved if there is more news about how the institution runs or solves the problem than how it actually becomes the source of the problem. Cumulative negative effects will occur if, on the contrary, more news about the institution ignores road damage or corruption or so on. This statement is an empirical statement and therefore can be examined. This research is aimed at examining empirically the situation in the community in an area of Indonesia.

The originality of this research lies in empirical proof of the conceptual account of knowledge activation theory combined with attribution theory of responsibility. Both theories have never been combined before in one study so this study contains originality in this aspect.

\section{Research Methodology}

This research uses a qualitative approach. A qualitative approach is ideal for exploring complex topics (Miles, Huberman, 1994) and this research can be said to be complex because it involves aspects of news readings that reveal hidden elements, as opposed to the elements seen in the news. Truly so, complexity is reduced by referring only to the problem of attribution of responsibility in the news narrative.

The focus of this study is on public service and mass media. In particular, the public service in focus is the Tapin Regency Public Works and Spatial Planning (PWSP) Service Office, South Kalimantan. The PWSP in Tapin Regency is one of the government agencies which provide public services to the community in Tapin Regency, South Kalimantan. This service is important for improving the quality of road and drainage infrastructure in the area. The mass media here acts as a detector of the situation in the field, program observers, and at the same time reports to the public on public performance. Therefore, it becomes important to see a balance between these functions. If the mass media too build up a negative perception of the government, then this becomes an important public management problem to overcome. In line with this, this study seeks to learn how the PWSP's service is perceived by the mass media and how to improve the perception of the mass media to support the program of Tapin Regency PWSP Service.

Meanwhile, the focus of mass media is directed to the news made by the mass media on the public services provided by the Tapin Regency PWSP Service. The focus on every news item is to find the attribution of the responsibilities given by each piece of news to the source of the causes and solutions. The PWSP service is then positioned in the news, either as a cause or as a prob- 
lem solver. The sample for the analysis in this research is news from the mass media about the PWSP Service which disseminated online. Each news item contains two units of analysis: the attribution of responsibility and the attribution of problem solving.

Data collection was done online. Researchers used the Google News search engine to find news with the keywords "Public Works Department" along with "Tapin Regency". The term "Public Works" was used because in general society and media are more familiar with PWSP Service under the name of Public Works Department. This is evidenced by the use of the phrase "Dinas PUPR (PWSP)" "KabupatenTapin (Tapin Regency)" only found two news items, while the phrase "Dinas PU (Public Works Department)" "KabupatenTapin" obtained 52 news items. The amount of 52 news items is considered to be enough to be able to conduct a qualitative analysis.

Data analysis is done by a descriptive and qualitative method by searching for words that show the actors in the news. The role of these actors is then examined within the framework of whether the actor is responsible for the cause or for the solution. In accordance with the theory of attribution, the PWSP Service must be one of these roles. Qualitative analysis is then done to weigh the weight of the responsibility assigned by the media to the PWSP Service in each news item.

\section{Media Attribution to Public Works Performance}

Of the 52 news stories found, 30 are relevant to the PWSP Office of Tapin Regency. Of these 30,28 came from the Banjarmasin Post, while one came from Malang Today and one from Tempo. Six of the news items were from 2015, 12 from 2016, and 12 from 2017. The biggest news portion is the coverage about the heavily damaged road, which featured in 13 news stories, while eight were about broken bridges. The rest were news about narrow roads, prone trails, market access, homecoming and backflow, houses in danger of collapsing, damaged waterways, avalanches, floods, and the beauty of green space.

From the 30 headlines, 18 talked about the planning stages of development, such as the road maintenance or road inspection by the PWSP Office. There are nine stories about the development process, i.e. measures such as bridge iron security or site reviews. There are only three news items that show the results of development such as the completion of road construction or road improvements.

Meanwhile, when viewed over time, positive development outcomes tend to increase more sharply than negative development news (development issues). In 2015 there were four news stories about roads and bridges while in 2017 there were six. On the other hand, in 2015 there were only two positive news stories while in 2017, six items (or 50\%) were positive news.

The majority (24) of the news stories attributed road users and bridges to causal responsibility. Other responsibilities appearing in the news were about contractors, nosy people, market traders, truck riders, tourists, and House members, as well as related agencies. There is only one piece of news that 
implies that the PWSP Service is responsible for the cause, from a reportfrom 5 July, 2017 entitled "Bupati Urges Offices to beautify Rantaubaru". The use of the word "urges" implies a causal attribution to the services because the word "urges" means the preceding has actually been ordered but not or not yet optimal. Included in the offices urged was the PWSP Office. Indeed, if only seen from this aspect of causal attribution, the PWSP Office is in a safe situation because it is hardly considered a cause of the problems faced by society regarding development.

Since only one causal attribution is given to the PWSP Service, 29 other news items automatically attribute the maintenance responsibility to the PWSP Office. This is a favorable finding because it means that the public appreciates the PWSP Service. But this should be supplemented with more news content.

When viewed from the news content, it was found that 21 of the 30 news stories emphasized the problem and only nine emphasized the solution to the problem. That is, even though the PWSP Office is positively attributed, the problem persists. This means that the PWSP Office is not fully described as a problem solver. They are only expected to be problem solvers and have responded with a promise to solve the problem. Of the 30 news stories, the news explicitly speaks of the PWSP Office's active action so the problem is lost to only three pieces: the news about the PWSP Office building an access road to Margasari's new market, the PWSP Office repairingAntasari Bridge, and the PWSP Offices that paved the way with Hotmix asphalt. The rest is about the PWSP Office responding and promising to get off to the field, hoping to pave the way, will prioritize it in the next fiscal year, and so on. The following table details the role of PWSP in each news item.

The interesting thing found in these news items is that there is gender bias in three of the stories. In the report about the bad condition of Gadung-Masta road (Banjarmasin Post, 31 December, 2016), it said that motorists find it difficult to cross, especially women. It also said that every female rider who carries passengers is forced to ask her passenger to go on foot and, after successfully passing the muddy road, the passenger then gets back onagain. In the news story of October 1, 2016, women even became part of the headline: "Streets Like an Offroad Track, Women Off Their Bikes", even though the photo shows a mother riding a motorcycle, not guiding it on foot. This news comes from the same street - Gadung-Masta street. Meanwhile, in one letter, a reader complained about Bintahan Road being too narrow; it was stated that mothers who delivered their kids to kindergarten fell from their bike every month because of the muddy road.

The existence of gender bias in news and public reports on road use has scientific justification. A. Morgan and F.L. Mannering's (2011) research as well as previous researchers confirm that there is a gender difference in the risk of road accidents. These gender differences stem from behavioral and physiological differences between male and female drivers. Because it is scientifically justified, the existence of gender bias in the news is actually positive in terms of showing public and media awareness of the vulnerability of women as victims of damaged road conditions. 


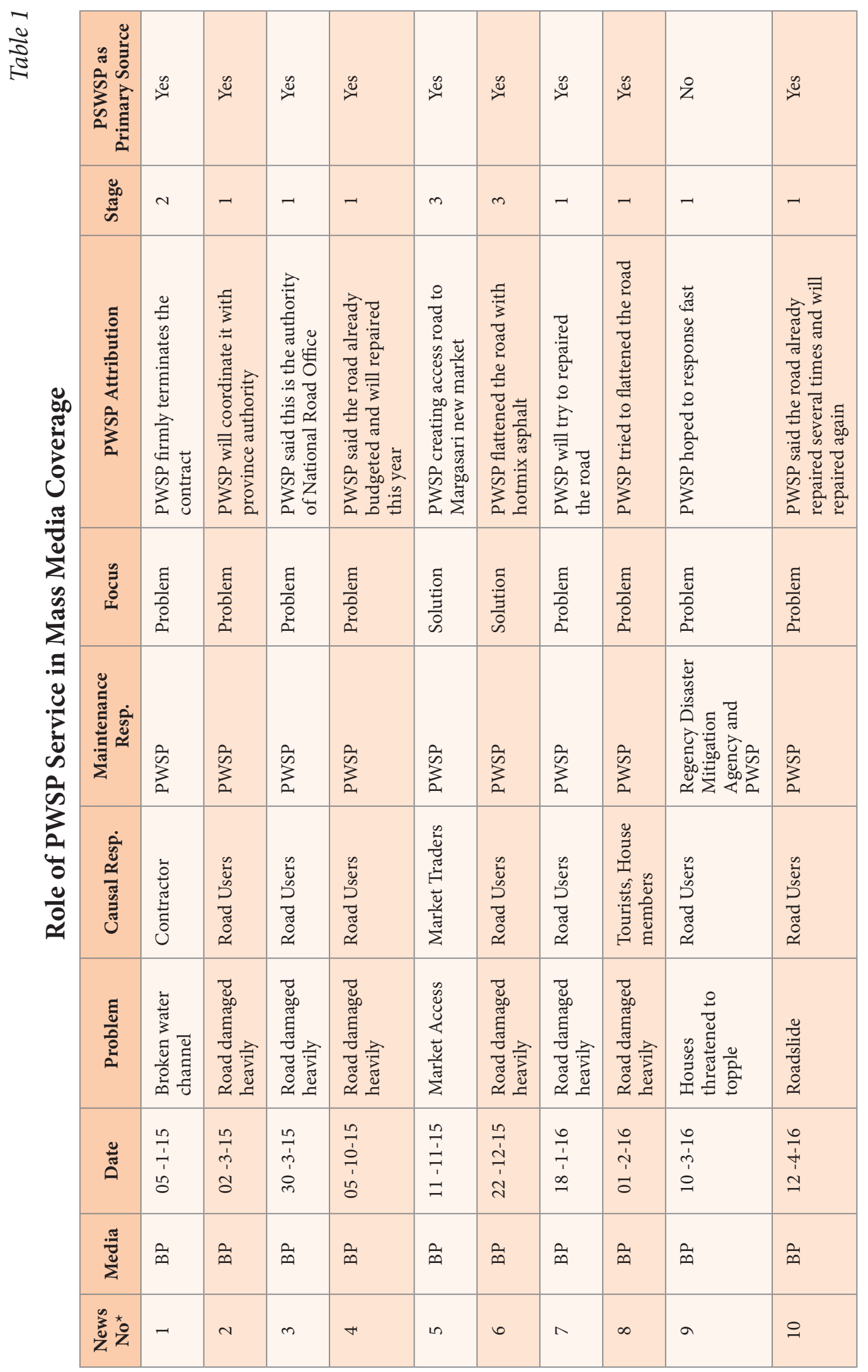




\begin{tabular}{|c|c|c|c|c|c|c|c|c|c|c|c|c|}
\hline 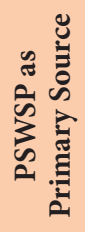 & $\stackrel{\circ}{z}$ & ¿े & 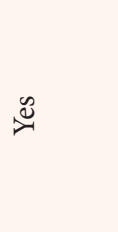 & 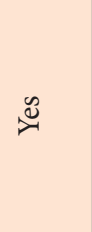 & $\stackrel{\infty}{\approx}$ & $\approx$ & $\approx$ & $\approx$ & $\approx$ & $\stackrel{\varpi}{\approx}$ & $\stackrel{\circ}{z}$ & $\approx$ \\
\hline $\begin{array}{l}\text { 品 } \\
\text { 苛 }\end{array}$ & - & $\sim$ & - & $\sim$ & $\sim$ & - & - & - & - & - & - & $\sim$ \\
\hline 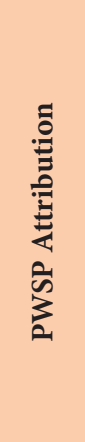 & 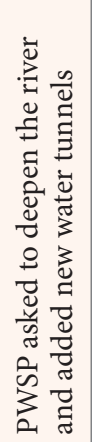 & 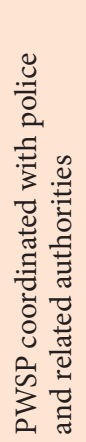 & 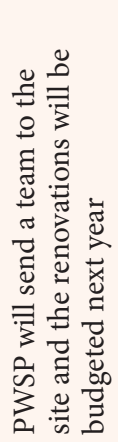 & 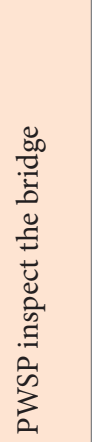 & 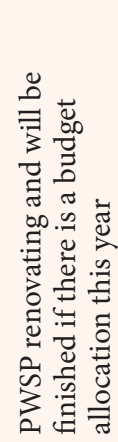 & 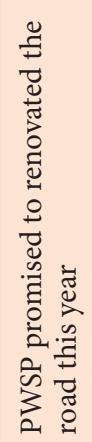 & 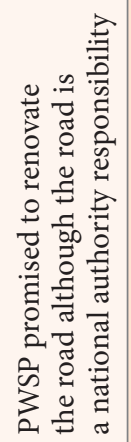 & 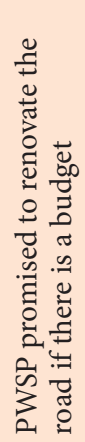 & 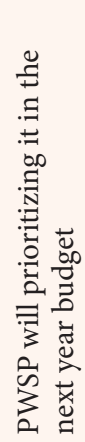 & 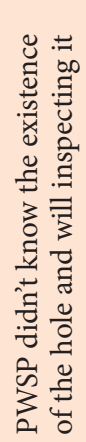 & 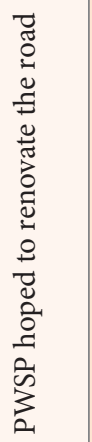 & 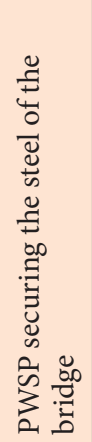 \\
\hline 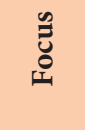 & $\begin{array}{l}\frac{E}{0} \\
\frac{0}{0} \\
0 \\
0\end{array}$ & $\begin{array}{l}\text { 泀 } \\
\text { 咅 }\end{array}$ & $\begin{array}{l}\text { : } \\
\frac{0}{0} \\
0 \\
0 \\
0\end{array}$ & $\begin{array}{l}\frac{\Xi}{0} \\
\frac{0}{2} \\
\vdots \\
0\end{array}$ & $\begin{array}{l}\text { : } \\
\frac{0}{00} \\
0 \\
0 \\
0\end{array}$ & $\begin{array}{l}\frac{\Xi}{0} \\
\frac{0}{0} \\
0 \\
0\end{array}$ & $\begin{array}{l}\frac{\Xi}{0} \\
\frac{0}{0} \\
0 \\
0\end{array}$ & $\begin{array}{l}\text { घี } \\
\frac{0}{00} \\
0 \\
0\end{array}$ & 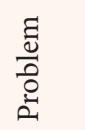 & $\begin{array}{l}\text { है } \\
\frac{0}{0} \\
0 \\
0\end{array}$ & $\begin{array}{l}\text { घ: } \\
\frac{0}{0} \\
0 \\
0 \\
0\end{array}$ & $\begin{array}{l}\text { : } \\
\text { 泀 } \\
\text { क }\end{array}$ \\
\hline 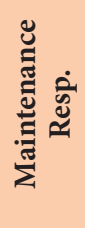 & $\sum_{0}^{\infty}$ & 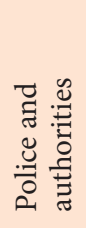 & 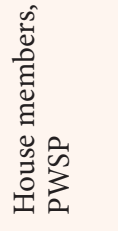 & $\begin{array}{l}\text { के } \\
\sum_{0} \\
0 \\
\stackrel{0}{0} \\
0 \\
0\end{array}$ & 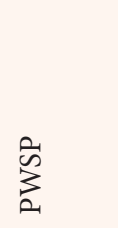 & 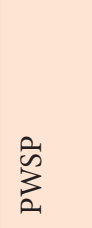 & $\begin{array}{l}\text { के } \\
\sum_{0}^{2}\end{array}$ & 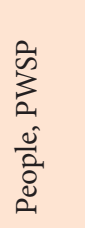 & 离 & 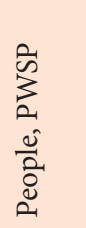 & 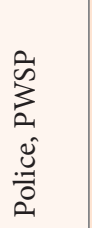 & 离 \\
\hline 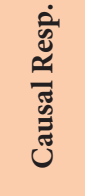 & 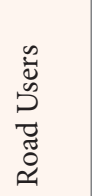 & 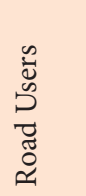 & 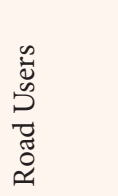 & 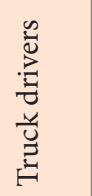 & 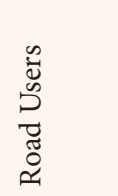 & 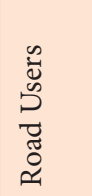 & 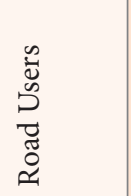 & 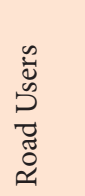 & 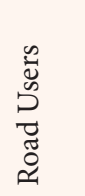 & 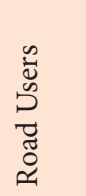 & 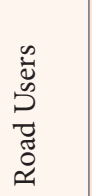 & 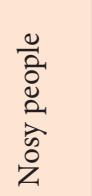 \\
\hline 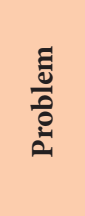 & $\begin{array}{l}\overrightarrow{0} \\
\stackrel{0}{I}\end{array}$ & 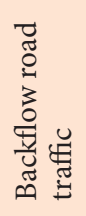 & 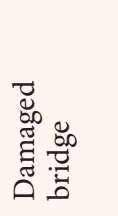 & 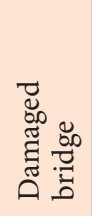 & 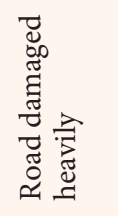 & 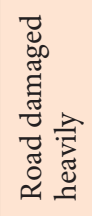 & 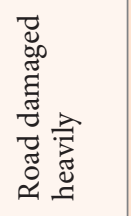 & 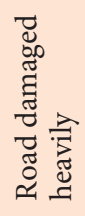 & 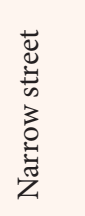 & 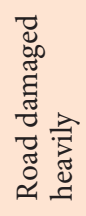 & 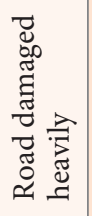 & 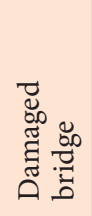 \\
\hline 气ัँ & $\begin{array}{l}\stackrel{0}{1} \\
\stackrel{+}{1} \\
\stackrel{2}{a}\end{array}$ & $\begin{array}{l}0 \\
\underline{b} \\
i \\
\vec{\sim}\end{array}$ & $\begin{array}{l}0 \\
1 \\
1 \\
\\
0\end{array}$ & $\begin{array}{l}0 \\
1 \\
1 \\
0 \\
0\end{array}$ & $\begin{array}{l}0 \\
\overline{1} \\
\hat{n} \\
n\end{array}$ & $\begin{array}{l}0 \\
01 \\
0 \\
11 \\
0\end{array}$ & $\begin{array}{l}0 \\
\stackrel{1}{1} \\
\stackrel{1}{1} \\
1 \\
0 \\
e\end{array}$ & $\begin{array}{l}0 \\
\stackrel{1}{1} \\
\stackrel{1}{1} \\
\vec{m}\end{array}$ & $\begin{array}{l}\stackrel{7}{1} \\
=\end{array}$ & $\begin{array}{l}\stackrel{-}{1} \\
\stackrel{1}{a}\end{array}$ & $\begin{array}{l}\hat{\vec{n}} \\
\dot{1} \\
\dot{\sigma}\end{array}$ & $\begin{array}{l}\hat{1} \\
\hat{1} \\
\infty\end{array}$ \\
\hline 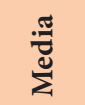 & $\stackrel{\oplus}{n}$ & 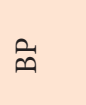 & $\vec{n}$ & $\stackrel{\oplus}{n}$ & $\vec{\infty}$ & $\ddot{\infty}$ & $\vec{\infty}$ & $\vec{n}$ & $\vec{\infty}$ & $\vec{m}$ & $\vec{n}$ & $\vec{m}$ \\
\hline$\hat{z}_{z}^{*}{ }^{*}$ & $=$ & $\stackrel{\sim}{工}$ & $\stackrel{m}{\sim}$ & $\Xi$ & $\stackrel{2}{\sim}$ & $\mathscr{\sim}$ & $\bumpeq$ & $\stackrel{\infty}{\sim}$ & $\curvearrowright$ & ㄱ. & $\vec{\sim}$ & $\tilde{\sim}$ \\
\hline
\end{tabular}




\begin{tabular}{|c|c|c|c|c|c|c|c|c|c|}
\hline 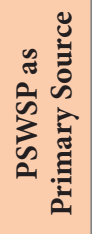 & $\stackrel{\varpi}{\approx}$ & $\stackrel{\circ}{Z}$ & $\stackrel{\varpi}{\approx}$ & $\stackrel{\infty}{\approx}$ & $\stackrel{\infty}{\approx}$ & $\stackrel{\circ}{z}$ & $\stackrel{\Perp}{\approx}$ & $\stackrel{\circ}{z}$ & \\
\hline 总 & $\sim$ & - & $\sim$ & $\sim$ & $\sim$ & - & $m$ & - & \\
\hline 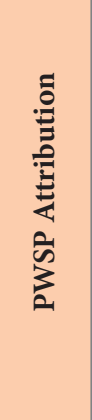 & 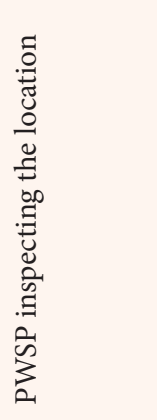 & 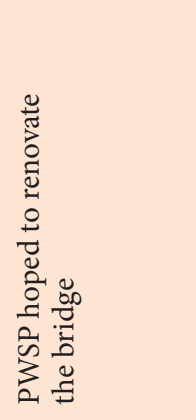 & 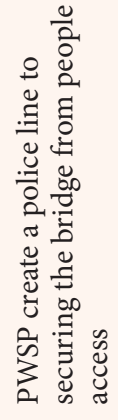 & 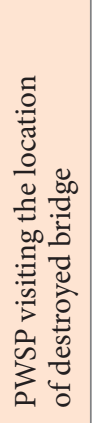 & 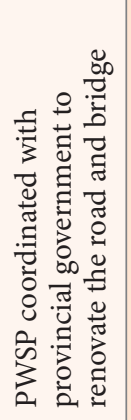 & 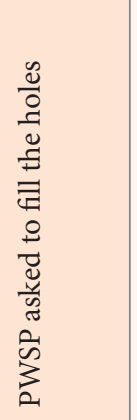 & 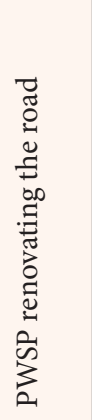 & 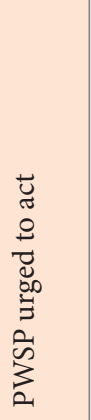 & \\
\hline 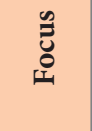 & 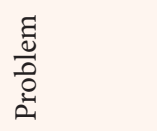 & $\begin{array}{l}\text { : } \\
\frac{0}{00} \\
0 \\
0\end{array}$ & $\begin{array}{l}\stackrel{\Xi}{0} \\
\stackrel{\Xi}{0} \\
\text { के }\end{array}$ & 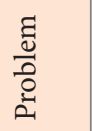 & 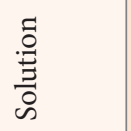 & $\begin{array}{l}\stackrel{0}{\Xi} \\
\stackrel{\Xi}{0} \\
\stackrel{0}{n}\end{array}$ & $\begin{array}{l}\stackrel{\Xi}{0} \\
\stackrel{5}{0}\end{array}$ & 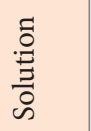 & \\
\hline 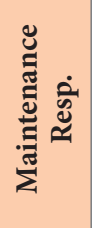 & 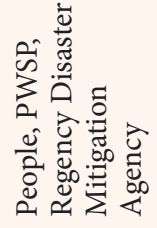 & 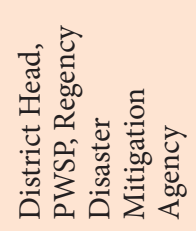 & 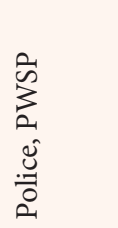 & 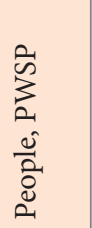 & 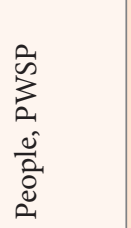 & 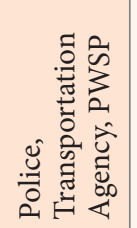 & 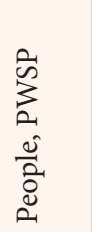 & 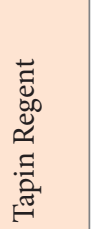 & \\
\hline 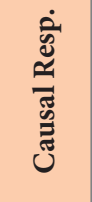 & 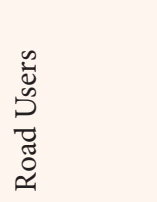 & 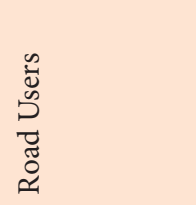 & 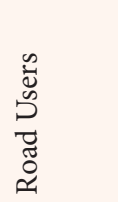 & 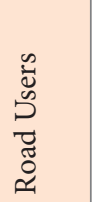 & 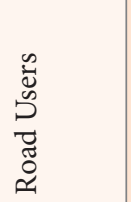 & 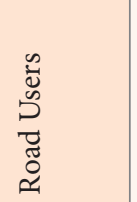 & 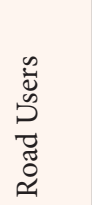 & 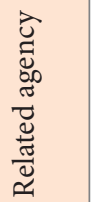 & 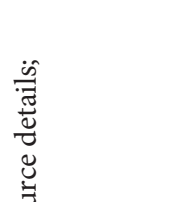 \\
\hline $\begin{array}{l}\frac{5}{0} \\
\frac{0}{0} \\
\frac{0}{2}\end{array}$ & 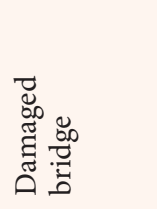 & 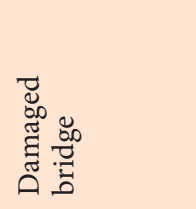 & 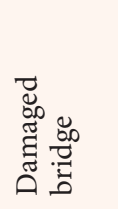 & 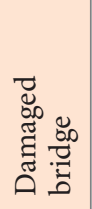 & 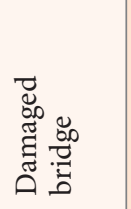 & 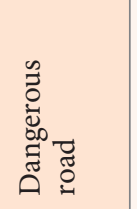 & 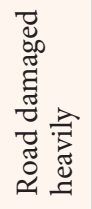 & 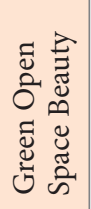 & 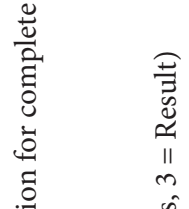 \\
\hline ڤँच & $\begin{array}{l}\stackrel{5}{I} \\
\stackrel{1}{I}\end{array}$ & 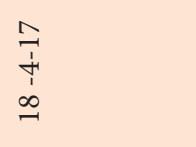 & $\begin{array}{l}\stackrel{1}{1} \\
\dot{7} \\
\stackrel{1}{2}\end{array}$ & $\begin{array}{l}\text { İ } \\
\text { †े } \\
\text { वे }\end{array}$ & $\begin{array}{l}1 \\
\hat{b} \\
1 \\
0\end{array}$ & $\begin{array}{l}1 \\
\hat{b} \\
1 \\
o\end{array}$ & $\begin{array}{l}0 \\
b \\
1 \\
m\end{array}$ & $\begin{array}{l}\hat{1} \\
\hat{1} \\
\stackrel{1}{0}\end{array}$ & 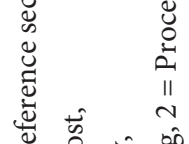 \\
\hline 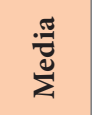 & $\stackrel{\rho}{\infty}$ & $\stackrel{E}{\Sigma}$ & $\stackrel{\rho}{\oplus}$ & $\stackrel{p}{\infty}$ & $\stackrel{p}{n}$ & 窎 & $\stackrel{\rho}{\infty}$ & $\stackrel{\oplus}{\infty}$ & 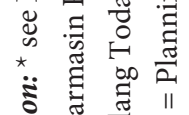 \\
\hline$\sum_{\tilde{z}}^{\infty}{ }^{\star}{ }^{\circ}$ & $\ddot{\sim}$ & $\stackrel{\sim}{N}$ & $\stackrel{\mathscr{\sim}}{\sim}$ & $\underset{\sim}{ }$ & $\hat{\sim}$ & $\stackrel{\infty}{\sim}$ & సิ & ి్లి & 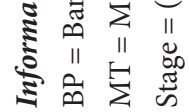 \\
\hline
\end{tabular}




\section{Mass Media Ignorance on Development Results}

At the beginning of his reign, President Joko Widodo implemented the Mental Revolution by asking the national mass media to report on more positive aspects of the nation's development and achievements (Metro TV News, 9 February, 2016). This has been welcomed by the national mass media, as evidenced by the many positive achievements and development events for the nation and country. However, the results of this study reveal that the spirit of the Mental Revolution has not been followed by the local media. The majority of the news presented (21 of 30 news items) discuss problems faced by the community in regards to development, from damaged roads to homes threatened with collapse. However, it is evident that there has been a positive development with more positive news regarding solutions by 2016 .

It is understandable that in the current information technology era, local mass media can only work on local news to gain a competitive advantage. When focusing on local news, even just on a few perforated roads, is necessary for local media to have unique news that is not owned by competing media. This should be positive because it gives the impression that the mass media is concerned with the condition of the community in the region, although perhaps the real reason is simply to get the unique news that can only be reached by the mass media, which in turn can be commodified as a product that generates economic value.

Of course, the mass media can claim that they are trying to convey that which the government cannot reach. If people want to obtain positive news about the development and achievement of a government agency, they can refer to the site of the relevant agency. On the websites managed by the Public Relations Service, we found positive news about the construction of roads and so forth. But if this is the case, surely we cannot find any positive news in the local mass media news. Things like this are not found in the above results. Some of the news was really positive, stating that a road had been repaired or that the PWSP was willing to repair the road even though it was not authorized or not yet budgeted. That is, the mass media can actually lift positive news in the same amounts but with negative news. For example, from the news about problems faced by the community, they can also make news about progress or completion of the solution to the problem. News about damaged roads in one particular place, for example at Parigi Bridge, Tapin, could be offset by news about the PWSP Office that has finished repairing the bridge so that the public can pass without any misgivings. But this is not the case. From the data, we do not see the existence of any continuity of news from the moment the problem is proposed, processed, and finally solved.

As a result, the role of mass media only goes one way, that is, from society to government, but not vice versa. In order for channels to be reciprocated, the government must open its own communication channels in the form of news submitted by their respective PR. For example, the Tapin District PWSP Office used their site to deliver news about a well-executed program. Unfortunately, this is not as effective as the mass media. The mass media has a broad consumer base because it is profit-oriented. From a NPM perspective, mass media has better efficiency 
and effectiveness than government sites. If positive news is only given by the official website, then there will be the impression that this is just a one-sided claim. For example, the public complaints about road damage in front of the regent's house were disclosed by the Banjarmasin Post on December 30, 2016, but the completion of the road repair process was not found in the Banjarmasin Post, yet the improvements have been made and were submitted through the PWSP Office website on 5 April, 2017.

This becomes a further problem when the media often use superlative words in delivering the news. Some superlative phrases have been found in the stories stated above. Among these superlative phrases include the "urges" (Banjarmasin Post, July 5, 2017), "many bridges were destroyed" (Banjarmasin Post, July 10, 2016), "for months but no improvement" (Banjarmasin Post, December 30, 2016), "the police are restless and anxious" (Banjarmasin Post, March 4, 2017), "ragged bridge" (Banjarmasin Post, Oct. 1, 2016; Banjarmasin Post, June 23, 2016), "weeping in fear" (Banjarmasin Post, March 10, 2016), and "always just get blank promises" (Banjarmasin Post, February 1, 2016). It is understandable that the use of superlative phrases is directed to attract the attention of the reader. But if this applies to the reporting of the solution to the problem, it certainly will give great attention to the reader as well.

The attribution theory of responsibility affirms that the government will be perceived positively by society if the media attributes the public service as a solution to the problem their faced with. This research indicates that the government, in this case the PWSP Office, is already attributed positively. However, this attribution is weak because most attributions are provided only at the planning stage, such as a promise to fix or a preliminary review of damaged roads or bridges. In order to increase government attribution, the PWSP Office needs to act more proactively by inviting the mass media to attend when a project has been completed, especially those media that had previously preached about the problem. In this way, there will be a continuity of news between the early problem and the settlement of the problems undertaken by the PWSP Office. Furthermore, this will improve the positive image of the PWSP Office in the eyes of the people of Tapin Regency.

This effort should also support the PWSP Service activities, especially in the IT field, by publishing performance indicators and PWSP Office achievements on the website. In addition, road lists and bridges programmed for improvement need to be disclosed to the public, either through the media or on the PWSP Service website so that the public can get a clear picture of the performance of the PWSP Office as well as shape expectations of what roads or bridges will be repaired immediately. This will meet the transparency criteria demanded by New Public Management.

Another strategy is that the PWSP Office needs to actively communicate with surrounding communities when visiting sites with road and bridge damage problems so that the surrounding community knows what progress is going on and what steps the government is working on. The inspecting party shall be provided with knowledge or information on the budget and program schedule to be undertaken by the PWSP Office so that the community will acquire experiential knowl- 
edge that can be used to weigh up their opinions regarding the problem of road damage. Without experiential knowledge, people can only rely on mass media that can preach a problem in excess and cause a lack of confidence in the government.

\section{Challenges Required for Government}

to Improve Public Perception through Mass Media

This study implies the need for the PWSP Office to be more transparent in showing the work program and its performance in the community so that the community can obtain experiential knowledge that can be used to weigh up their opinions related to the problem of road damage. This is in line with the theory of knowledge activation which states that the basis of human reasoning lies in the aspects of empirical experience and media coverage. The knowledge of the PWSP Office directly and quantitatively enables communities to weigh up qualitative news that can be biased when coming from mass media coverage.

Another implication is that the PWSP Office needs to partner with the mass media more closely so as to convey the progress and the achievement of the project. Without closer cooperation, the media only becomes a channel from society to government, not from government to society. With only one path from society to government, the government will be perceived negatively as media news tends to show the problems that the government has not yet completed in the field. This does not mean that this path is disconnected, as the media runs and facilitates the government's task of detecting problems occurring in the field. If the media only transmits information from government to society, it can be viewed as a propaganda tool. That is, there must be a clear and gradual flow from society to government and from government to society.

The third implication is more related to the Problem of the PWSP Service itself. In some news, the PWSP Office is talking about fixing a road or a bridge if the available budget is available. Therefore, the public and the media need to know what the budget is, what its allocation is for capital expenditure, and which bridges or roads are planned to be fixed within the budgetary year.

\section{Implication for Attribution Theory of Responsibility}

This research has implications on the theory of attribution of responsibility by providing qualitative characteristics of the theory. The attribution of responsibilities given by the theory does not rely on whether responsibility is causal or maintenance. This study implies that the attribution of responsibilities is not only necessary to distinguish between who is the cause of the problem and who is the problem solver, but also implies that the problem solvers need to be differentiated between, i.e., the different problem solvers in the planning / preparation stage, the implementation stage, and the result stage.

This research proposes that the attribution of care in the theory of attribution responsibility will have the greatest positive effect when the attribution actors are at the outcome stage of the project, rather than at the implementation stage or at the planning stage. 


\section{REFERENCES}

1. Ballesteros, B.C. (2012). Determinant factors of functional decentralisation and externalisation of local public services. PhD Dissertation. University of Salamanca

2. Bengston, D.N., Potts, R.S., Fan, D.P., \& Goetz, E.G. (2005). An Analysis of the Public Discourse about Urban Sprawl in the United States: Monitoring Concern about a Major Threat to Forests. Forest Policy and Economics, vol. 7, no 5, pp. 745-756.

3. BPS KabupatenTapin (2016). Statistik Daerah Kabupaten Tapin 2016 [Tapin Regency Statistics 2016]. Rantau: BPS KabupatenTapin

4. Constantinescu, A.R. \& Tedesco, J.C. (2007). Framing a Kidnapping: Frame Convergence between Online Newspaper Coverage and Reader Discussion Posts about Three Kidnapped Romanian Journalists. Journalism Studies, vol. 8, no 3, pp. 444-464.

5. Dinas PUPR Kabupaten Tapin [Tapin PWSP Agency] (5 April, 2017). Patching Jalan di Depan Rumah Bupati dan Pendopo Sudah Baik [Road Patching in front of Regent House and Pendopo Finished]. Available at: https://dinaspu.tapinkab.go.id/2017/04/05/patchingjalan-didepan-rumah-bupati-dan-pendopo-sudah-baik/ (accessed: 4 July, 2017).

6. Gamson, W.A. (1992). Talking Politics. New York: Cambridge University Press.

7. Hamot, G.E., Shiveley, J.M. \&VanFossen, P.J. (1997). Media Literacy in Social Studies Teacher Education: Relating Meaning to Practice. Annual Meeting of the American Educational Research Association, Chicago, March 24-28

8. Iyengar, S. (1989). How Citizens Think about National Issues: A Matter of Responsibility. American Journal of Political Science, no 33, pp. 878-900.

9. Iyengar, S. (1991). Is Anyone Responsible? How Television Frames Political Issues. Chicago: University of Chicago Press.

10. Metro TV News (9 February, 2016). Presiden Minta Pers Membangun Optimisme [President Asks Press to Build Optimism]. Available at: http://news.metrotvnews.com/read/2016/02/09/481390/ presiden-minta-pers-membangun-optimisme (accessed: 4 July, 2017).

11. Miles, M.B. \& Huberman, A.M. (1994) Qualitative Data Analysis: An Expanded Sourcebook, 2nd edn. Sage, Thousand Oaks, CA, USA

12. Morgan, A. \& Mannering, F.L. (2011). The Effects of Road-Surface Conditions, Age, and Gender on Driver-Injury Severities. Accident Analysis \& Prevention, vol. 43, no 5, pp. 1852-1863.

13. Porumbescu, G. (2016). Not All Bad News after All? Exploring the Relationship between Citizens' Use of Online Mass Media for Government Information and Trust in Government. International Public Management Journal, December, pp. 1-33.

14. Price, V. \& Tewksbury, D. (1997). News Values and Public Opinion: A Theoretical Account of Media Priming and Framing. In: George A. Barnett and Franklin J. Boster (eds). Progress in the Communication Sciences, Greenwich, CT: Ablex.Google Scholar, pp. 173-212.

15. Price, V., Tewksbury, D. \& Powers, E. (1997). Switching trains of thought: The impact of news frames on readers' cognitive responses. Communication Research, vol. 24, no 5, pp. 481-506.

16. Ridhahani, H., Ahdi, M. \&Wahyudin, W. (2016). Pengaruh Akses Pemberitaan Media Massa Terhadap Komitmen Revolusi Mental Birokrasi Dalam Pelayanan Publik Di Kalimantan Selatan [The Effect of Mass Media Coverage Access on the Mental Revolution Commitment of The Bureaucratic in Public Service in South Kalimantan]. IAIN Antasari Banjarmasin. 
17. Thomas, S. (2014). Submission to the New Zealand Productivity Commission 'More Effective Social Services Inquiry'. Australian National University.

18. Wang, H., Warner, M.E., Tian, Y. \& Zhu, D. (2014). Public Owner with Business Delivery Mode in China: Case Study of the Shanghai Public Bus System. Annals of Public and Cooperative Economics, vol. 85, no 1, pp. 147-164.

19. Wetterberg, A. \& Brinkerhoff, D.W. (2016). The Political Economy of Public Reform Adoption: Patterns in Twenty Indonesian Regency's. International Public Management Journal, vol. 19, no 4, pp. 476-512.

\section{NEWS USED IN THE ANALYSIS}

1. Banjarmasin Post (05 Januari, 2015). Proyek Saluran Air Tak Selesai, PU Tapin Putus Kontrak [Unfinished water channel project, Tapin PWSP terminating the contract]. Available at:http://banjarmasin.tribunnews.com/2015/01/05/proyek-saluran-air-tak-selesai-pu-tapinputus-kontrak (accessed: 24 July, 2017).

2. Banjarmasin Post (02 Maret, 2015). Hindari Kecelakaan, Warga Tanam Pisang di Badan Jalan [Avoiding accidents, residents planting bananas on the road]. Available at: http://banjarmasin. tribunnews.com/2015/03/02/hindari-kecelakaan-warga-tanam-pisang-di-badan-jalan (accessed: 24 July, 2017).

3. Banjarmasin Post (30 Maret, 2015). Jalan Nasional a Yani Semakin Banyak Berlubang [A Yani National Road Potholes Increasing In Number]. Available at: http://banjarmasin.tribunnews. com/2015/03/30/jalan-nasional-a-yani-semakin-banyak-berlubang (accessed: 24 July, 2017).

4. Banjarmasin Post (05 Oktober, 2015). Jalan Pasar Baru Keraton Tapin Rusak [Tapin Pasar Baru Keraton Road damaged]. Available at: http://banjarmasin.tribunnews.com/2015/10/05/ jalan-pasar-baru-keraton-tapin-rusak (accessed: 24 July, 2017).

5. Banjarmasin Post (11 November, 2015). Pasar Margasari Baru di Tapin Mulai Dibenahi [New Margasari Market in Tapin gets prepared]. Available at: http://banjarmasin.tribunnews. com/2015/11/11/pasar-margasari-baru-di-tapi-mulai-dibenahi (accessed: 24 July, 2017).

6. Banjarmasin Post (22 Desember 2015). Demi Kenyamanan Peserta dan Pengunjung, Jalan Menuju Lokasi Baayun Maulid Dimuluskan [For the Convenience of Participants and Visitors, Road to Baayun Maulid Finished]. Available at: http://banjarmasin.tribunnews. com/2015/12/22/demi-kenyamanan-peserta-dan-pengunjung-jalan-menuju-lokasibaayun-maulid-dimuluskan (accessed: 24 July, 2017).

7. Banjarmasin Post (18 Januari, 2016). Gorong-Gorong Pecah, Jalan Menuju Sentra Perkebunan Bawang di Tapin Ambruk [Culvert cracked, road to Sentra Onion Plantation at Tapin collapsed] Available at: http://banjarmasin.tribunnews.com/2016/01/18/gorong-gorongpecah-jalan-menuju-sentra-perkebunan-bawang-di-tapin-ambruk (accessed: 24 July, 2017).

8. Banjarmasin Post (01 Februari 2016). Jalan ke Makam Datu Nuraya Tapin Rusak, Jadi Langganan Janji Calon Wakil Rakyat [Road to Tomb of Datu Nuraya Tapin Damaged, We Always Get Promises with No Realization from House Members]. Available at:http://banjarmasin. tribunnews.com/2016/02/01/jalan-ke-makam-datu-nuraya-tapin-rusak-jadi-langgananjanji-calon-wakil-rakyat (accessed: 24 July, 2017).

9. Banjarmasin Post (10 Maret, 2016). Rahmina Menangis Ketakutan Rumahnya di Tepi Sungai Tapin terancam Ambruk [Rahmina Cried With Fear As Her House on the Edge of Tapin River 
Threatens to Collapse]. Available at:http://banjarmasin.tribunnews.com/2016/03/10/rahminamenangis-ketakutan-rumahya-di-tepi-sungai-tapin-terancam-ambruk (accessed: 24 July, 2017).

10. Banjarmasin Post (12 April, 2016). Tak Jauh dari Rumah Jabatan Bupati Tapin, Jalan yang Longsor ini Belum diperbaiki [Not far From Tapin Regent's House, This Landslided Road Has Not Been Fixed]. Available at: http://banjarmasin.tribunnews.com/2016/04/12/takjauh-dari-rumah-jabatan-bupati-jalan-pahlawan-tapin-yang-longsor-belum-diperbaiki (accessed: 24 July, 2017).

11. Banjarmasin Post (19 April, 2016). Banjir Rendam Empat Rumah di Tapin [Four Homes Flooded in Tapin]. Available at: http://banjarmasin.tribunnews.com/2016/04/19/banjir-rendamempat-rumah-di-tapin (accessed: 24 July, 2017).

12. Banjarmasin Post (21 Juni, 2016) Polres Tapin Pasang Spanduk Mengantuk [Tapin Police Erect Sign Warning Drivers of Drowsiness]. Available at: http://banjarmasin.tribunnews. com/2016/06/21/polres-tapin-pasang-spanduk-mengantuk (accessed: 24 July, 2017).

13. Banjarmasin Post (23 Juni, 2016). Sudah Saatnya Jembatan Tangkawang Tapin diganti Beton [It is the Time for Tangkawang Tapin Bridge to be Replaced by a New Concrete Bridge]. Available at: http://banjarmasin.tribunnews.com/2016/06/23/sudah-saatnya-jembatantangkawang-tapin-diganti-beton (accessed: 24 July, 2017).

14. Banjarmasin Post (10 Juli, 2016). Warga Ngeri Melintas Jembatan Parigi Tapin, Lubangnya Seukuran Truk [Truck-sized Hole on Parigi Tapin Bridge, People Afraid to Pass]. Available at: http://banjarmasin.tribunnews.com/2016/07/10/warga-ngeri-melintas-jembatan-parigitapin-lubangnya-seukuran-truk (accessed: 24 July, 2017).

15. Banjarmasin Post (13 September, 2016). Jalan SMPN 1 Binuang Belum Mulus dan Banjir Saat Hujan, Dikeluhkan Warga dan Siswa [SMPN 1 Binuang Road Not Yet Smooth and Floods During Rainfall, Public and Students Complain]. Available at: http://banjarmasin.tribunnews. com/2016/09/13/jalan-smpn1-binuang-masih-belum-mulus-dan-banjir-saat-hujan-dikeluhanwarga-dan-siswa (accessed: 24 July, 2017).

16. Banjarmasin Post (01 Oktober, 2016). Jalanan Seperti Lintasan Offroad, Kaum Wanita Terpaksa Tuntun Motornya [Streets Like an Offroad Track, Women Off Their Bikes]. Available at: http://banjarmasin.tribunnews.com/2016/10/01/jalanan-seperti-lintasan-offroad-kaumwanita-terpaksa-tuntun-motornya (accessed: 24 July, 2017).

17. Banjarmasin Post (30 Desember, 2016). Parah! Jalan di Depan Rujab Bupati Berlubang [Danger! Road in Front of Regent Official House Holed]. Available at: http://banjarmasin.tribunnews. com/2016/12/30/parah-jalan-di-depan-rujab-bupati-berlubang (accessed: 24 July, 2017).

18. Banjarmasin Post (31 Desember, 2016). Awas Terpeleset Lewat Jalan Gadung Masta! [Beware of Slipping on GadungMasta Road]. Available at: http://banjarmasin.tribunnews. com/2016/12/31/awas-terpeleset-lewat-jalan-gadung-masta (accessed: 24 July, 2017).

19. Banjarmasin Post (11 Januari 2017). Jalan Bitahan Terlalu Sempit [Bintahan Road Too Narrow]. Available at: http://banjarmasin.tribunnews.com/2017/01/11/jalan-bitahan-terlalu-sempit (accessed: 24 July, 2017).

20. Banjarmasin Post (19 Januari, 2017). Awas Lubang Besar di Jalan By Pass Rantau [Watch out for the Big Hole on Rantau Bypass Road]. Available at: http://banjarmasin.tribunnews. com/2017/01/19/awas-lubang-besar-di-jalan-by-pass-rantau (accessed: 24 July, 2017).

21. Banjarmasin Post (04 Maret, 2017). Jalan Berlubang di By Pass Bikin Polisi Tapin Gelisah [Damaged Road in Bypass Made Tapin Police Anxious]. Available at: http://banjarmasin. tribunnews.com/2017/03/04/jalan-berlubang-di-by-pass-bikin-polisi-tapin-gelisah (accessed: 24 July, 2017). 
22. Banjarmasin Post (08 Maret, 2017). Kadis PU Tapin: Segera Amankan Besi Jembatan [Head of PWSP Office: Secure the Bridge's Steel Immediately]. Available at: http://banjarmasin.tribunnews. com/2017/03/08/kadis-pu-tapin-segera-amankan-besi-jembatan (accessed: 24 July, 2017).

23. Banjarmasin Post (17 April, 2017). RusakSejak 2013, Warga Baramban Tapin Takut Melintas [Damaged since 2013, Baramban Tapin People Fear Crossing]. Available at: http://banjarmasin. tribunnews.com/2017/04/17/rusak-sejak-2013-warga-baramban-tapin-takut-lewat-jembatan (accessed: 24 July, 2017).

24. Malang Today (18 April, 2017). Pemkab Tapin Terpaksa Tutup Jembatan Dele, Kenapa? [Tapin Regency Government forced to close Dele Bridge. Why?] Available at: https://malangtoday.net/ flash/nasional/pemkab-tapin-terpaksa-tutup-jembatan-dele-kenapa/ (accessed: 24 July, 2017).

25. Banjarmasin Post (19 April, 2017). JembatanBungurTapindipasangiGarisPolisi [TapinBungur Bridge Fitted with Police Line]. Available at: http://banjarmasin.tribunnews.com/2017/04/19/ jembatan-bungur-tapin-dipasangi-garis-polisi (accessed: 24 July, 2017).

26. Banjarmasin Post (29 April, 2017). Jembatan di Tapin ini Bikin Warga Waswas Saat Melintas [This Bridge in Tapin Makes Citizens Worried When Passing By]. Available at: http:// banjarmasin.tribunnews.com/2017/04/29/jembatan-di-tapin-ini-bikin-warga-waswas-saatmelintas (accessed: 24 July, 2017).

27. Banjarmasin Post (08 Juni, 2017). Jembatan Antasari Tapin Akhirnya Diperbaiki [Antasari Tapin Bridge Finally Renovated]. Available at: http://banjarmasin.tribunnews.com/2017/06/08/ jembatan-antasari-tapin-akhirnya-diperbaiki (accessed: 24 July, 2017).

28. Tempo (09 Juni, 2017). Ramadan 2017, Jalur Mudik di Kalsel dan Kalteng Siap Dilintasi [Holiday Traffic Route in South and Central Kalimantan Ready to Cross]. Available at: https://ramadan.tempo.co/read/news/2017/06/09/151882996/ramadan-2017-jalurmudik-di-kalsel-dan-kalteng-siap-dilintasi (accessed: 24 July, 2017).

29. Banjarmasin Post (13 Juni, 2017). Jalan Berlubang di Rantaubaru Disemen [Holed road in Rantaubaru cemented]. Available at: http://banjarmasin.tribunnews.com/2017/06/13/ jalan-berlubang-di-rantaubaru-disemen (accessed: 24 July, 2017).

30. Banjarmasin Post (05 Juli, 2017). Bupati Desak Dinas Mempercantik Rantaubaru [Regent Urges Offices to Beautify Rantaubaru]. Available at: http://banjarmasin.tribunnews. com/2017/07/05/bupati-desak-dinas-mempercantik-rantaubaru (accessed: 24 July, 2017). 